$\overline{\text { 報 交 }}$

献立における調理素材と調理法の相互関係

一フィリピンのメニュー・カレンダーを資料として——

川端晶子, 澤 山 茂, Lutgarda S. Palomar*

東京農業大学, *ビサヤ国立農科大学

\title{
Relationship between Ingredients and Cooking Methods in Menus from "Your Regional Menu Guide" of the Philippines
}

\author{
Akiko Kawabata, Shigeru Sawayama and Lutgarda S. Palomar* \\ Tokyo University of Agriculture ; *Visayas State College of Agriculture, Philippines
}

The relationship between ingredients and cooking methods in a menu calender called "Your Regional Menu Guide" published by FNRI in the Philippines was studied by "Analysis of relativity of elementary technologies".

The results are as follows :

1) The number of dishes appeared in the menu calender was 3,414 . The total frequency of appearance of foodstuffs was 7,732 times, and they consisted of $29.1 \%$ of foods for energy source, $24.1 \%$ of foods for sources of body constituents, $41.8 \%$ of foods for regulation of body function, and $5.7 \%$ of miscellaneous foods. Among the ingredients, onion was used with the highest frequency followed by tomato, vegetable oil, fresh fish, garlic and non-glutinous rice in this order.

2) The combination of onion and tomato was observed most frequently and it appeared 470 times with the relativity of 0.6752 . This was followed by combinations of onion and garlic, onion and vegetable oil, garlic and vegetable oil, tomato and vegetable oil, tomato and garlic, sugar and coconut, and fresh fish and onion, in this order.

3) As for the frequency of cooking methods, boiling marked the highest frequency followed by serving raw, frying, deep frying, baking and steaming, in this order. The foodstuff with the highest relativity to boiling was non-glutinous rice, followed by onion, fresh fish, tomato, sugar and coconut. The foodstuffs that showed the highest relativity on other cooking methods were: banana versus raw; vegetable oil versus stir frying; fresh fish versus deep frying; fresh fish versus baking; glutinous rice versus steaming.

4) The purpose of this calender seems to be an introduction of nutritiously improved recipes for a variety of recommendable menus that can be accepted and understood easily by people. For this purpose, FNRI carried out a very careful analysis of the result of National Nutrition Survey in consideration of natural, social, and cultural conditions that have long been the background of their dietary habits, and printed the collection of menus on their calender for each month of the year.

$$
\text { Jpn. J. Nutr., } 43 \text { (6) 289 299 }
$$

Key words : analysis on relativity of elementary technologies, frequency, frequency of co-occurrence, relativity, structure of dishes

要素技術連関解析, 出現頻度, 共出現頻度, 連関度, 料理構造 


\section{緒言}

広義の栄養学の中で食べ物に焦点を合わせるならば, “何故に，何を，如何に食べるか”といら 3 つの観点 より考えることができるが，この“如何に食べるか”を担当するのが調理学である。調理学は食物調製の最終 段階を受け持ら, 最む人間に密着し, 生命を保つための直接的な使命をるっている。人間は美味をこよなく愛 し，楽しい食事は身体を養うとともに，心の糧ともなり，人間にとって最も幸せなひとときでもある。

調理学はその対象が日常茶飯事のものであり, 体験の積み重ねから発達してきた技術が優先し, 複雑多岐な 要素が多すぎるため, 理論体系が後手後手に回されがちであった。豊川 ${ }^{122}$ は, 料理を要素とする理論体系が 脆弱であることを指摘し, 料理を要素とする栄養学の理論体系の構築の急務を力説している。また, 足立滛の 料理選択型栄養教育の枠組としての核料理とその構成に関する研究は, 上記命題に, 栄養教育の立場から新し い一石を投じたといえよう。しかし, 調理学の立場からは, 食文化をも踏まえ, 実際の食生活の指導にも役立 つ料理を要素とした食学 425$)$ の理論体系を築くべく，一翼を担わねばならない。理論体系を築くためには，構 造的把握が大切である。構造とは, 構成要素間の相互関係を総称するものであるが, 料理の構成要素は調理素 材と調理法である。

調理は, 食べ物の素材から料理を作るための処理で ある(り)といことができるが, ‘素材と調理法は多種多 様であり, 実際の調理の大部分はこれらの複雑な組み 合わせである。さらに, 料理には, これを摂取する人 の住む自然・地理的環境, また, 社会的・文化的条件 が密接に関与していることも考慮しなければならな w。

本研究では, 調理素材としての食品と調理法を系統 的に整理し, それらの使用頻度と組み合わせの状態に ついて解析を試みた結果, 興味ある知見が得られたの で報告する。

\section{研 究 方 法}

\section{1. 資料}

フィリピンの科学開発庁 (National Science Development Boad : 現 National Science and Technology Authority) の众下にある食料栄養研究所 (Food and Nutrition Research Institute; FNRI) から発行され た，"Your Regional Menu Guide 1981”8)を資料とし て用いた。

フィリピンでは, 1978年に第 1 回国民栄養調査が行 われた が，このカレンダーは栄養調査の結果をもと に, 栄養指導を目的として作成された, おすすめメ ニ一集ともいうべきものである。月ごとに，地域別に

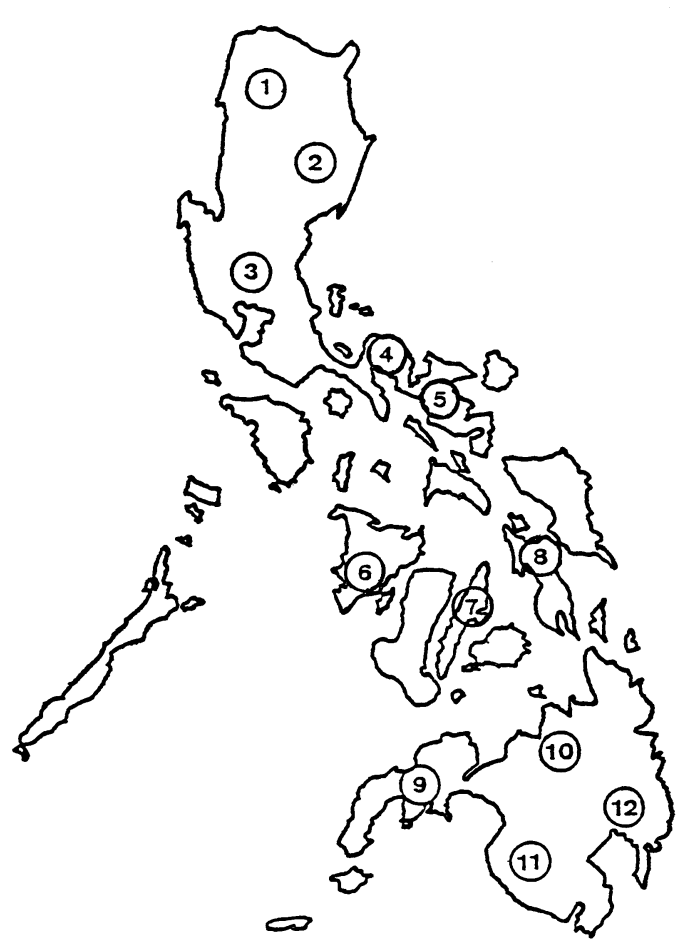

Fig. 1 Regional division in the "Your regional menu guide calender" $1:$ Ilocos, 2 : Cagayan Valley, 3 : Central Luzon, 4 : Southern Luzon, 5 : Bicol, $6:$ Western Visayas, $7:$ Central Visayas, 8 : Eastern Visayas, 9 : Western Mindanao, 10 : Northern Mindanao, 11 : Southern Mindanao, $12:$ Central Mindanao 
Table 1 Outline of indexing codes of foods and cooking methods

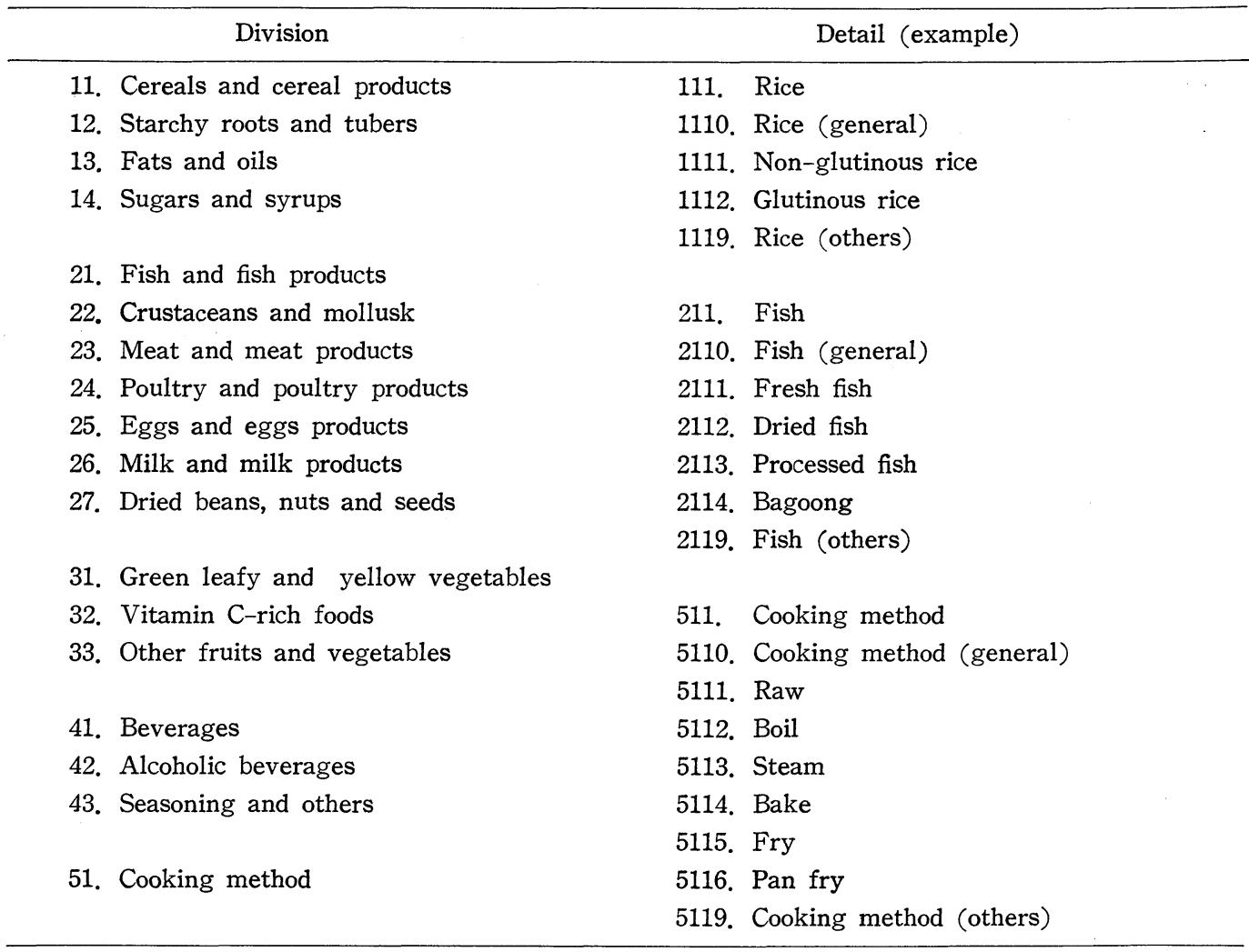

集録されているが,Fig. 1 と示すような区分である。すなわち, 'January : Ilocos, February : Cagayan Valley， March : Central Luzon, April : Southern Luzon, May : Bicol (以上, Louzon 地区), June : Western Visayas, July : Central Visayas, August : Eastern Visayas (以上, Visayas 地区), September : Western Mindanao, October : Northern Mindanao, November : Southern Mindanao, December : Central Mindanao （以上, Mindanao 地区）ょり構成されている。1 年間 365 日の朝, 昼, 夕食およびスナックの合計 3,414 種の 料理が記載されている。

\section{2. 解析方法}

解析には, 吉村 ${ }^{7}$ の要素技術連関解析の手法を用いた。まず, メニュー・カレンダーに記載されている料理

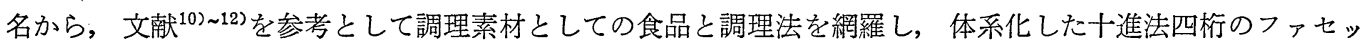
ト分類表 ${ }^{13)}$ を作成した。資料に記載されている各料理を分類表を用いて分析し，インデックスを付与した。分 類表の一部を Table 1 に示した。

フィリピンの国民栄養調査のまとめの項目に準拠し，エネルギー食品群を 1,000 番台，身体構成食品群を 2,000 番台, 機能調整食品群を 3,000 番台, その他を 4,000 番台, 調理法を 5,000 番台とした。また, Table 1 には，小分類の例として，米，魚および調理法の項目を示した。

各料理を表すフェースコードと，それに付与されたインデックスを単位レコードとし，ィニュー・カレンダ 一に収録されている全ての料理を含むデータベースを作成して, コンピューター（IBM 4331）を用い，解析 
に必要な各種の数値を算出した。

\section{結果}

\section{1. 調理素材（食品）の出現頻度}

1 年間の朝，昼，夕食およびスナックに登場している食品の出現頻度を食品群別にまとめ Table 2 に示し た。食品の出現頻度の合計は7,732回であったが，大別して，エネルギー食品群 $29.1 \%$, 身体構成食品群 24.1 \%, 機能調整食品群 $41.1 \%$ ，その他 $5.7 \%$ であった。特に，身体構成食品群中の魚介類の出現頻度の高いの が注目される。1978年の栄養調査の結果 ${ }^{6}$ では，1日 1 人当たりの摂取量は，魚介類 $102 \mathrm{~g}$, 肉類 $31 \mathrm{~g}$ ，卵類 8g となっているが，フィリピンでは魚介類が重要な動物性たん白質給源であることがわかる。

しかし，卵類の摂取量が $8 \mathrm{~g}$ というのは，FNRI から示されている摂取量の目安の $29.6 \%$ の充足率にすぎ ず，おすすめメニュー集では，卵類の利用頻度を多くし，摂取量の増加を配慮していることがうかがえる。

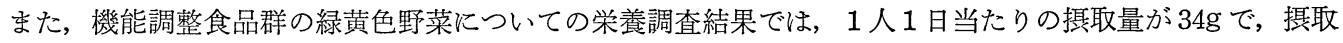
量の目安の $38.3 \%$ 充足率にすぎず，卵類と同様に摂取量増加を配慮したものと考えられる。

Table 3 には, 月別, すなわち, 地域別の食品, 料理数および 1 つの料理に用いられる食品数を示した。ル ソン，ビサヤおよびミンダナオ地区に大別すると，食品および料理数の出現頻度はルソン地区がやや多くなっ

Table 2 Frequencies of annual use of each food

\begin{tabular}{|c|c|c|}
\hline Division & Frequency & $\% *$ \\
\hline$\langle$ Energy foods $\rangle$ & 2,245 & 29.1 \\
\hline 11. Cereals and cereal products & 791 & 10.3 \\
\hline 12. Starchy roots and tubers & 202 & 2.6 \\
\hline 13. Fats and oils & 577 & 7.5 \\
\hline 14. Sugars and syrups & 675 & 8.7 \\
\hline$\langle$ Body biulding foods $\rangle$ & 1,865 & 24.1 \\
\hline 21. Fish and fish products & 704 & 9.1 \\
\hline 22. Crustaceans and mollusk & 181 & 2.3 \\
\hline 23. Meat and meat products & 164 & 2.1 \\
\hline 24. Poultry and poultry products & 30 & 0.4 \\
\hline 25. Eggs and eggs products & 169 & 2.2 \\
\hline 26. Milk and milk products & 233 & 3.0 \\
\hline 27. Dried beans, nuts and seeds & 384 & 5.0 \\
\hline$\langle$ Regulating foods〉 & 3,178 & 41.1 \\
\hline 31. Green leafy and yellow vegetables & 481 & 6.2 \\
\hline 32. Vitamin C-rich foods & 1,841 & 23.8 \\
\hline 33. Other fruits and vegetables & 856 & 11.1 \\
\hline$\langle$ Miscellaneous $\rangle$ & 444 & 5.7 \\
\hline 41. Beverages & 94 & 1.2 \\
\hline 42. Alcoholic beverages & 8 & 0.1 \\
\hline 43. Seasoning and others & 342 & 4.4 \\
\hline Total & 7,732 & 100 \\
\hline
\end{tabular}

* Percentage of frequency in the total foods 
Table 3 Number of dishes and foods in the "Your regional menu guide calender"

\begin{tabular}{llcccc}
\hline \multirow{2}{*}{ Month } & \multicolumn{1}{c}{ Region } & $\begin{array}{c}\text { Frequency } \\
\text { of foods }\end{array}$ & $\begin{array}{c}\text { Number of } \\
\text { varieties } \\
\text { of foods }\end{array}$ & $\begin{array}{c}\text { Number of } \\
\text { dishes }\end{array}$ & $\begin{array}{c}\text { Number of } \\
\text { foods } \\
\text { Dish }\end{array}$ \\
\hline January & Ilocos & 746 & 91 & 297 & 2.5 \\
February & Cagayan Valley & 697 & 77 & 268 & 2.6 \\
March & Central Luzon & 666 & 80 & 311 & 2.1 \\
April & Southern Luzon & 593 & 75 & 283 & 2.1 \\
May & Bicol & 627 & 79 & 299 & 2.1 \\
\cline { 2 - 6 } & Louzon (mean) & 666 & 80 & 292 & 2.3 \\
\hline June & Western Visayas & 595 & 76 & 288 & 2.1 \\
July & Central Visayas & 619 & 75 & 270 & 2.3 \\
August & Eastern Visayas & 625 & 73 & 281 & 2.2 \\
\cline { 2 - 6 } & Visayas (mean) & 613 & 75 & 280 & 2.2 \\
\hline September & Western Mindanao & 621 & 77 & 278 & 2.2 \\
October & Northern Mindanao & 632 & 72 & 283 & 2.2 \\
November & Southern Mindanao & 650 & 70 & 276 & 2.4 \\
December & Central Mindanao & 659 & 75 & 280 & 2.4 \\
\cline { 2 - 6 } & Mindanao (mean) & 640 & 74 & 279 & 2.3 \\
\hline & Total & 7,732 & 920 & 3,414 & 2.3 \\
\hline
\end{tabular}

ている。フィリピンは常夏の国であり, 平均温度は $5 \sim 10$ 月が $27 \sim 28^{\circ} \mathrm{C}, 11 \sim 4$ 月が $25 \sim 26^{\circ} \mathrm{C}$ で, 料理に表 れる季節の影響は少なく，むしろ，地域的な産物を生かした料理がメニューに加えられているのが注目された。

(1) ルソン地区

ルソン地区では， 1 月のメニューがルソン島北部のイロコス地方， 2 月がカガヤン川流域， 3 月がルソン島 の中央部，4 月がルソン島南部，5月がビコール地方となっている。

イロコス地方は山間部が多く, 耕地面積の少ない地域である。山岳民族の開拓したバナウェのラィステラス は有名で, 隔離された文化圈を構成し, 固有の伝統を守っていた。現在, バギオ周辺は高原野菜の栽培が盛ん であり，魚の利用頻度も高く，拈すすめメニュ一集では，食品の種類の最も多い地域であった。

カガヤン地域には, カガヤン谷とよばれる大きな平原があり, スペインの征服者がここに来たのは16世紀の ことであった。まだ未墾地もあるが，とうもろこしと稲作が主に行われている。おすすめメニニー集では， 1 つの料理に用いられている食品数が 2.6 種で, 最も多い地域であった。

ルソン島の中央部には, ルソン平野があり, 米, さとうきびを中心に, 野菜, 果実, ココナッツなどを生産 し, フィリピン随一の農業地域である。ぬた，魚介類も豊富である。首都マニラをもち，就すすめメニュー集 でも料理数の最も多い地域であった。

ルソン島南部地方は，山地，台地，平地がいりくんだ地形をもち，火山がもたらした肥沃な土と豊かな降水， それに加えてマニラといら大消費地を控えているので多様化した農業を営み, その生産物も多様化しているが, おすすめメニュー集での食品の出現頻度や料理数もきわ立って多くはない。

ビコール地方は, ルソン島東南部に位置し, かなり古くより開けた町がある。ココナッッとマニラ麻が主要 
な農産物であるが, 零細農家が多く, おすすめメニュー集では幾つかのココ ナッツ料理が注目される。

(2) ビサヤ地区

ビサヤ地区のメニューでは， 6 月が 西ビサヤ， 7 月が中央ビサヤ，8月が 東ビサヤ地方となっている。

西ビサヤ地方とは, ビサヤ諸島の西 端にあるパナイ島とネグロ島の地域を いら。パナイ島は,ルソン島やセブ島と 同様に古くょり閒けた島であり，人口 も多い。米, とうもろこし, 各種の野 菜が農産物となっているが，漁業も盛 んで, 塩干魚が多く生産されている。 マニラその他の地方への移出が多いた めか, 拈すすめメニュー集での食品の 利用頻度も少ない注うである。

中央ビサヤ地方では, 中央にあるセ ブ島がその中心をなしている。フィリ ピンの他の多くの地域が米食を主食と しているのに対しここでは珍しく,と うもろこしを主食とし，パンや米を秥 として食べている。豚や鷄の飼育も盛 んである。西洋文化を最も古くより取 り入れた地域でありメニュー集にも スペイン風の料理がみられる。

東ビサヤ地方で有数の農業地帯は, 肥沃な沖積平野が広がるレィテ平野で ある。米, とうもろこしが作られ，コ コナッツの生産量も多い。さつまいも, キャッサバ，タロなどのいも類も作ら れ，かなり食用にも供されている。お すすめメニュー集の中にも, いもの根 茎や葉を用いた料理がみられる。

(3) ミンダナオ地区

第 3 番目のグループのミンダナオ地 区のメニューでは，9月が西ミンダナ
Table 4 Frequencies of some main foods

\begin{tabular}{|c|c|c|}
\hline Food & Frequency & $\% *$ \\
\hline I. Cereals and cereal products & 791 & \\
\hline Non-glutinous rice & 348 & 44.0 \\
\hline Corn & 101 & 12.8 \\
\hline Bread & 77 & 9.7 \\
\hline Glutinous rice & 66 & 8.3 \\
\hline Miki style noodle & 23 & 2.9 \\
\hline Others & 176 & 22.3 \\
\hline II. Starchy roots and tubers & 202 & \\
\hline Sweet potato & 71 & 35.2 \\
\hline Potato & 35 & 17.3 \\
\hline Yam & 28 & 13.9 \\
\hline Taro & 27 & 13.3 \\
\hline Cassava & 26 & 12.9 \\
\hline Others & 15 & 7.4 \\
\hline III. Fats and oils & 577 & \\
\hline Vegetable oils & 488 & 84.5 \\
\hline Margarin & 62 & 10.8 \\
\hline Lard & 19 & 3.3 \\
\hline Butter & 4 & 0.7 \\
\hline Shortning & 4 & 0.7 \\
\hline IV. Fish, crustaceans and mollusks & 885 & \\
\hline Fresh fish & 436 & 49.3 \\
\hline Lobster, shrimp and crub & 105 & 11.9 \\
\hline Processed fish & 84 & 9.5 \\
\hline Dried fish & 64 & 7.2 \\
\hline Shells & 40 & 4.5 \\
\hline Others & 156 & 17. 6 \\
\hline V. Meats and eggs & 363 & \\
\hline Eggs & 138 & 38.0 \\
\hline Pork & 95 & 26.1 \\
\hline Beef & 32 & 8.8 \\
\hline Chicken & 29 & 7.9 \\
\hline Carabeef & 3 & 1.0 \\
\hline Others & 66 & 18.2 \\
\hline VI. Milk and milk products & 233 & \\
\hline Cow's milk & 151 & 64.8 \\
\hline Milk powder & 20 & 8.6 \\
\hline Cheese & 8 & 3.5 \\
\hline Carabao's milk & 5 & 2.1 \\
\hline Condenced milk & 5 & 2.1 \\
\hline Others & 44 & 18.9 \\
\hline VII. Vegetables & 2,564 & \\
\hline Onion & 593 & 23.1 \\
\hline Tomato & 580 & 22.6 \\
\hline Garlic & 356 & 13.9 \\
\hline Ginger & 103 & 4.0 \\
\hline Squash & 59 & 2.3 \\
\hline Others & 873 & 34.1 \\
\hline VIII. Fruits & 614 & \\
\hline Banana & 191 & 31.1 \\
\hline Papaya & 69 & 11.2 \\
\hline Mango & 40 & 6.5 \\
\hline Pineapple & 20 & 3.3 \\
\hline Jackfruit & 20 & 3.3 \\
\hline Others & 274 & 44.6 \\
\hline
\end{tabular}

* Percentage of frequency in the total of each group. 
オ，10月が北ミンダナオ，11月が南ミンダナオ，12月が中央ミンダナオである。明確な境界線をひきにくく， Table 3 に示されている食品や料理数の出現頻度でも，4 地方はかなり類似している。西，北ミンダナオはビ サヤ地方に共通する性格をもっている。米のほか, コーヒーや落花生も作られ，パイナップルの大農園もある。 おすすめメニュ一集にもパイナップル料理がみられる。南および中央ミンダナオでは, 米, とらもろこしのほ か, コーヒー, カカオも作られ，草地では牧牛も行われている。また，キャッサバを食料としている地域でも ある。おすすめメニュー集の中にも, ココナッツ, いも類の料理がみられる。

Table 4 に，出現頻度の高い素材を食品群別に 5 位までリストアップして示した。

穀類では，1位のうるち米が348回で，糓類の $44.0 \%$ 占め，とうもろこしが101回で 2 位であった。いも類 では，さつまいもが71回で35.2\%を占め，次いでじゃがいも 35回，ヤム 28回，タロ 27回，キャッサバ 26回 であった。油脂類では植物油が 1 位で 488回，84.5\%を占めていた。魚介類では生鮮魚が 1 位で 436回，49. 3 \%を占めているのに対し, 肉・卵類の出現頻度は低く, 卵は 1 位で138回，38.0\%，2位の豚肉は95回，26.1 \%であった。乳・乳製品では牛乳が151回，64.8\%で，2位の粉乳は20回，8.6\%であった。野菜類ではたまね

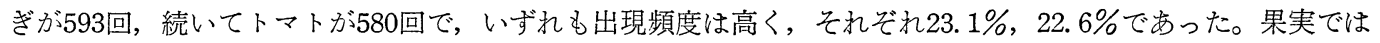
熱帯地域らしく，バナナ 191回，31.1\%で，2位のパパイヤは69回，11.2\%，続いてマンゴ，パイナップル， ジャックフルーッであった。

\section{2. 調理素材 (食品) の共出現頻度と連関度}

共出現頻度とは，2つの互いに異なる素材が同時に用いられる料理の数である。また，連関度とは，2つの Table 5 Frequencies of co-occurrence and relativities of pairs of main foods

\begin{tabular}{lccc} 
& Pair of foods & $\begin{array}{c}\text { Frequency of } \\
\text { co-occurrence }\end{array}$ & Relativity* \\
\hline 1. Onion & - Tomato & 470 & 0.6752 \\
2. Onion & - Garlic & 229 & 0.3220 \\
3. Onion & - Vegetable oil & 221 & 0.2587 \\
4. Garlic & - Vegetable oil & 211 & 0.3370 \\
5. Tomato & - Vegetable oil & 185 & 0.2106 \\
6. Tomato & - Garlic & 171 & 0.2258 \\
7. Sugar & - Coconut & 161 & 0.2346 \\
8. Onion & - Fresh fish & 102 & 0.1106 \\
9. Vegetable oil & - Eggs & 94 & 0.1678 \\
10. Vegetable oil & - Fresh fish & 84 & 0.1003 \\
11. Onion & - Pork & 68 & 0.1105 \\
12. Fresh fish & - Garlic & 66 & 0.0916 \\
13. Tomato & - Vinegar & 65 & 0.0947 \\
14. Onion & - Vinegar & 64 & 0.0915 \\
15. Glutinous rice & - Sugar & 59 & 0.1010 \\
16. Non-glutinous rice & - Sugar & 58 & 0.0671 \\
17. Eggs & - Onion & 57 & 0.0814 \\
18. Sugar & - Milk & 56 & 0.0836 \\
\hline * Relativity & & & \\
\hline
\end{tabular}

* Relativity $=\mathrm{F}_{\mathrm{A}} \cdot \mathrm{B} /\left(\mathrm{F}_{\mathrm{A}}+\mathrm{F}_{\mathrm{B}}-\mathrm{F}_{\mathrm{A}} \cdot \mathrm{B}\right)$

$\mathrm{F}_{\mathrm{A}}$ : Frequency of sample $A$

$F_{B}$ : Frequency of sample $B$

$\mathrm{F}_{\mathrm{A}} \cdot \mathrm{B}:$ Frequency of co-occurrence of samples $\mathrm{A}$ and $\mathrm{B}$ 
素材が同時に用いられる関係の深さを示し，次式によって求められる。

$$
\mathrm{R}=\mathrm{F}_{\mathrm{A}} \cdot \mathrm{B} /\left(\mathrm{F}_{\mathrm{A}}+\mathrm{F}_{\mathrm{B}}-\mathrm{F}_{\mathrm{A}} \cdot \mathrm{B}\right)
$$

ここで, R は連関度, $\mathrm{F}_{\mathrm{A}}$ は素材 $\mathrm{A}$ の出現頻度, $\mathrm{F}_{\mathrm{B}}$ は素材 $\mathrm{B}$ の出現頻度であり, $\mathrm{F}_{\mathrm{A}}$. B は素材 $\mathrm{A}$ と B の共 Table 6 Cooking methods and co-appeared foods $(\mathrm{R}>0.1)$

\begin{tabular}{lccll}
\hline $\begin{array}{c}\text { Cooking } \\
\text { method }\end{array}$ & Frequency & $\begin{array}{c}\text { Weight in } \\
\text { Percentage }\end{array}$ & Co-appeared food & Relativity \\
\hline Raw & 476 & 16.1 & Banana & 0.1440 \\
Boil & 842 & 28.4 & Non-glutinous rice & 0.1758 \\
& & & Onion & 0.1530 \\
& & & Fresh fish & 0.1381 \\
& & & Tomato & 0.1325 \\
& & & Sugar & 0.1167 \\
Steam & 233 & 2.5 & Coconut & 0.1161 \\
Bake & 304 & 1.9 & Glutinous rice & 0.1181 \\
Fry & & & Fresh fish & 0.2449 \\
& 436 & 14.8 & Fresh fish & 0.1786 \\
Pan fry & & & Vegetable oil & 0.1721 \\
& & & Vegetable oil & 0.4249 \\
& & & Garlic & 0.3316 \\
& & & Onion & 0.2958 \\
Others & 585 & \multirow{2}{*}{19.8} & Tomato & 0.2414 \\
& & & Eggs & 0.1750 \\
& & & Cow's milk & 0.1928 \\
& & & Coffee & 0.1145 \\
\hline
\end{tabular}

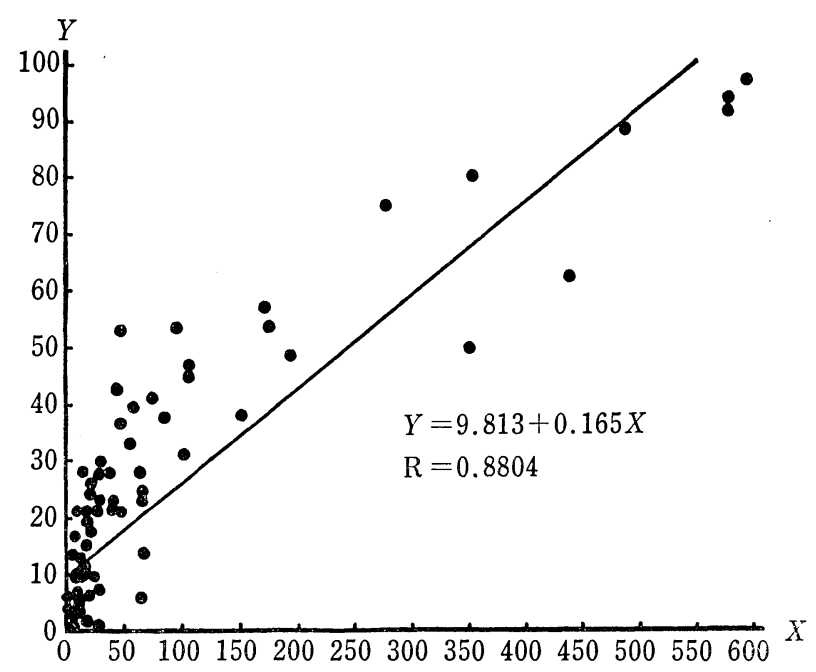

Fig. 2 Relationship between frequencies of foods and the kinds of related foods $X:$ Frequencies of all foods $Y:$ Kinds of the related foods
出現頻度である。

Table 5 飞, 共出現頻度上位18位ま でを示した。玉ねぎとトマトの共出現 頻度は470回であり, 連関度は 0.6752 といら高い值が得られた。続いて，玉 ねぎとにんにく，玉ねぎと植物油，に んにくと植物油, トマトと植物油, ト マトとにんにく, 砂糖とココナッッ, 玉ねぎと生鮮魚の組み合わせの順であ った。特徴的なこととして，玉水ぎと トマトの組み合わせが顕著に多く，ま た，玉ねぎやにんにくと植物油との共 出現頻度が高いことは, 炒め物には玉 ねぎやにんにくがたびたび用いられる ことを示唆し，ココナッツ，もち米お よび米と, 砂糖との共出現頻度の高い ことは, 菒子（もち菓子を含む）とし 
ての利用度の高いことを示している。18位までの中にはあげられていないが，鷄肉と牛肉との組み合わせなど もあり，食文化を背景としたフィリピン料理の特徴をらかがい知ることができた。

Fig. 2 飞, 各素材の出現頻度 $(X)$ と, これとともに用いられる素材の種類 $(Y)$ の関係を示した。 $X$ と $Y$ の間に, 一次回帰式 $Y=9.813+0.165 X$ が求められ，相関係数は 0.8804 であった。出現頻度の高い素材は, 多種類の他の素材と同時に用いられることを示している。しかし，かなり遠距離にスポットされているものに， 豚肉やキャベッなどがあるが，これらの出現頻度はそら高くはなく，多種類の素材と組み合わされて出現して いることを示している。

\section{3. 調理法と調理素材 (食品) の組み合わせ}

スープ拉よび甘味物を除く 2,951 種（合計料理数の $85.5 \%$ ）の料理について，各種調理法の出現頻度および 素材との組み合わせを Table 6 に示した。1 位は“煮る”で，出現頻度は842回，28.4\%を占めていた。2 位 は“生”，3位は“炒める”，4位は“揚げる”，5位は“焼く”，6位は“蒸す”の順となっていた。また，各 調理法と連関度 0.1 以上の素材を示したが，“煮る”と連関度の最も高い食品はうるち米で，続いて，玉枚ぎ， 生鮮魚, トマト, 砂糖, ココナッツの順であった。“生”ではバナナ, “炒める”では植物油との連関度が 0.4249 と高い值を示し，つづいて，にんにく，玉ねぎ，トマト，卵の順であった。“揚げる”では，鮮魚，植物油， “焼く”では, 鮮魚, “蒸す”ではもち米であった。

以上のように, メニューを構成する料理構造の解析を試み, 妥当な結果を得ることができた。

\section{考察}

本資料に用いたフィリピンのメニュー・カレンダーは, 1978年，第 1 回フィリピン国民栄養調査結果をもと に，適切な栄養を通して国民のよりよい健康を増進することを目的として作成されたものであるが，特に，栄 養状態の好ましくない地域や集団, 家庭に対しての栄養改善を推進するうえでの, 解りやすくまた親しみやす い媒体として歓迎されていた。

フィリピンは, アジア大陸の東南，マレ一諸島の東北部に散在する大小約 7,000 の島からなっている。年平 均気温は $27^{\circ} \mathrm{C}$ で， 1 年中ほとんど温度の差はないが，雨季（ 5 〜 月 ) と乾季（11〜 4 月）に分かれ，12〜 2 月は比較的涼しく，4〜5月が最も暑い。1978年末の人口は約 4,630 万人であるが，増加率は非常に高い。 人口密度は, マニラ周辺が最も高く, ついで, 中央ルソン, 中央ビサヤ, 西ビサヤ, ビコール地方となってい て，カガヤンバレー，ミンダナオ地区は最も低い。フィリピン住民はマレー族を主体として，原始民族，中国 人，スペイン人などの混血民族である。

昔からフィリピン人は数多くの島に散らばって生活していたが，共通な風俗習慣をもっていて，肥沃な土地 に恵まれ，交易が盛んで，経済も発展していた。その後，スペイン文化の影響，さらにアメリカ文化の流入と いう歷史的背景を反映して，これらの混合した文化の流れをもっているが，近年，これに民族的性格を強化し ようとする傾向がみられる。

食事文化には, 自然, 社会, 文化などの諸条件が背景となっているが, メニュー・カレンダーに集録されて いる料理にも，各地域の産物を生かしながら，歴史によって培われ，庶民の生活にも浸透しているスペイン風 や中国風の調理法が取り入れられていることが注目される。

フィリピン人の食生活の実態包は必ずしも満足すべきものではなく，食品群別 1 人平均食品消費量の推薦所 要量に対する充足率で, 約 $100 \%$ の食品群は, 穀類とその製品, 砂糖・糖蜜およびその他の果物・野菜類のみ 
である。特に，充足率の低い卵 $(29.6 \%)$, 乳・乳製品 $(34.4 \%)$ および緑黄色野菜 (38.3\%) については, おすすめメニュー集に最大の関心が払われていることが認められた。

エネルギー供給食品群では米, 身体構成食品群では魚が多く用いられているが, 肉類は細切れとして煮込み 料理に用いられている。

常夏の国であり，湿度も一般に高い地域なので，料理には酸味をきかせ，にんにくやこしょうなどの香辛料 であっさりと調味するのが特徴である。

一方, 都市に住む人は, 地方に住む人よりも一般に栄湌摂取レベルが高く，ルソン地方はビサヤおよびミン ダナオに比べて最も高くなっている。また, 栄養摂取レベルが相対的に高いのは, 高所得者層, 知的職業・工 業從事者や特殊技術者などであり, 驚くほど栄養摂取レベルが低いのは, 世帯主が農場労働者や小漁師, 雇わ れ漁師などの低所得者世帯で，貧富の差がそのまま栄養摂取レベルの高低に影響を与えている。

フィリピン人の食生活に打ける自耕自給産物の占める割合は, 高所得者の都市世帯では $5.8 \%$ あるのに対 し, 地方の低所得者世帯では $37.5 \%$ と高い比率を占め, メニュー・カレンダーでは, 地方の産物の利用が工夫 されているのがらかがえる。また, 家庭の食事計画者が高度の学校教育を受けているほど, その食生活に和け る食物消費や栄養摂取レベルにもプラスの効果が現れていることも報告されている゙๋が，FNRI は，国民栄養 調査の結果をきめ細かく分析したうえで,メニュー・カレンダーを通じて, 誰にでも解りやすく, すぐ役立つ 栄養改善の効果をねらっているといえよう。

健康は国家繁栄の基盤であり，栄養失調者のいる国は，社会的にも，経済的にも，開発途上国の証拠ともな るという考え方から, 特に, 将来の国を背負っていく子ども達の栄養問題については熱心であり, 並々ならぬ 努力が払われている。

本論文においては，献立における調理素材と調理法の相互関係を明らかにしたが，食生活指導の実践活動に は, 栄養素を要素とした理諭体系, 食品を要素とした理論体系とともに, 料理を要素とした理論体系を基盤に もつことが，人間文化に根ざす食のあり方を大局的にとらえていくらえで，重要であることを痛感するもので ある。

\section{要 約}

フィリピンのメニュー・カレンダー（Your Regional Menu Guide）を資料とし, 要素技術連関解析の手法 を用いて，献立における調理素材と調理法の相互関係の解析を行い，以下のような結果を得た。

1）メニュー・カレンダーに記載されている料理数は 3,414 件であった。食品の出現頻度の合計は7, 732回で あったが，大別して，エネルギー食品群 $29.1 \%$, 身体構成食品群 $24.1 \%$, 機能調整食品群 $41.1 \%$, その他 $5.7 \%$ でった。出現頻度の最も高い食品は玉ねぎで, つついて, トマト, 植物油, 生鮮魚, にんにく, うる ら米の順であった。

2）調理素材の共出現頻度は, 玉ねぎとトマトが470回であり, 連関度は 0.6752 が求められた。つづいて, 玉ねぎとにんにく，玉祀ぎと植物油，にんにくと植物油，トマトと植物油，トマトとにんにく，砂糖とココナ ッツ，玉ねぎと生鮮魚の組み合わせの順であった。

3）調理法の出現頻度では“煮る”が最も高く,つついて“生”, “炒める”, “揚げる”, “焼く”, “蒸す”の 順であった。“者る”と連関度の最も高い食品はうるち米で, つついて, 玉ねぎ, 生鮮魚, トマト, 砂糖, コ コナッツの順であった。“生”ではバナナ，“炒める”では植物油，“揚げる”では生鮮魚，“焼く”でも生鮮魚， 
“蒸す”ではもち米が最も高い連関度を示した。

4）総括してみるならば, 食料栄養研究所 (FNRI) は, フィリピンの食生活の背景となっている自然, 社 会, 文化の諸条件もふまえ, 国民栄養調査の結果をきめ細かく分析したうえで, おすすめメ二ュ一集をカレン ダーにまとめ, 誰にでも解りやすく，すぐ役立つ栄養改善の効果をねらったものであるということができる。

本研究を行らにあたり, 終始ご懇切なご指導を賜りました東京農業大学総合研究所 故 吉村典夫 助教授に厚 く御礼申し上げます。

なお, 本研究の一部は第36回日本栄養・食糧学会総会（東京）において報告した。

文献

1）豊川裕之 : 栄養学雑誌, 42,323 (1984)

2）豊川裕之：栄養日本, 28, 357 (1985)

3）足立己幸 : 民族衛生，50，50（1984）

4）石毛直道 : 地球時代の食の文化一食の文化シンポジゥム'82一, p. 279 (1982) 平凡社

5）太田泰弘：食のことば/柴田 武, 石毛直道編, p. 15 (1983) ドメス出版

6) 吉村典夫 : 調理科学, 13, 191 (1980)

7）吉村典夫：ドクメン ケンキュウ, 30, 160 (1980)

8) Food and Nutrition Research Institute, ed. "Your Regional Menu Guide 1981" Philippines (1981)

9) Food and Nutrition Research Institute, ed. : First National Nutrition Survey, Philippines, 1978, FNRI Publication No. GP-11 (1981)

10) Alvarez, H. V. : Philippine Cookery and Household Hints (1981) Uliran Publishing and Trading Corp., Manila

11) Perez, E. D. : Recipes of Philippines (1973) National Book Store, Manila

12) Arroyo, P. T. : The Science of Philippines Foods (1974) Abaniko Enterprise, Ouenzon

13) Yosimura, T. : Library and Information Science, 19, 211 (1981)

（受付：昭和60年 9 月 10 日） 